\title{
Evaluation of tomato hybrids for resistance to root knot nematode (Meloidogyne incognita)
}

\author{
K. Sundharaiya* and M. Karuthamani \\ Tamil Nadu Agricultural Univesity, COIMBATORE (T.N.) INDIA \\ (Email : primehorts@gmail.com)
}

\begin{abstract}
Three new tomato (Solanum lycopesicum L.) hybrids were evaluated for their reaction to the root knot nematode, Meloidogyne incognita, in comparison with their parents and resistant and susceptible check cultivar/hybrid in three different geographical locations in Tamil Nadu, India. The biochemical traits of the tested cultivars and hybrids were also compared. The resistant parent $\mathrm{HN} 2$ showed less root knot nematode females per gram of roots, number of eggmasses per gram of roots and root knot index. The newly synthesized tomato hybrid HN2 $\times$ CLN 2123A registered the least number of root knot nematode females per gram of roots, number of eggmasses per gram of roots and root knot index. The reaction to the nematode of the hybrid was at par with the resistant check Hisar Lalit. Also, the hybrids registered the greatest fruit yield per plant, plant height, number of branches per plant, number of fruits per plant and root length. The biochemical traits phenol content and root ascorbic acid content and the enzymes peroxidase, IAA oxidase and acid phosphatase activity were greatest in the hybrid HN $2 \times$ CLN $2123 \mathrm{~A}$. These biochemical traits excelled both parents, which would indicate the role of over dominant genes.
\end{abstract}

Key Words : Solanum lycopersicum, Evaluation-root-knot nematode, Resistance

View Point Article : Sundharaiya, K. and Karuthamani, M. (2018). Evaluation of tomato hybrids for resistance to root knot nematode (Meloidogyne incognita). Internat. J. agric. Sci., 14 (1) : 76-84, DOI: 10.15740/HAS/IJAS/14.1/76-84.

Article History : Received : 08.05.2017; Revised : 10.11.2017; Accepted : 23.11.2017

\footnotetext{
* Author for correspondence:
} 